\title{
A DETAILED CBCT STUDY OF 'CORONOID FORAMINA' AND ACCESSORY FORAMINA OF THE MANDIBLE: A UNIQUE ANATOMIC VARIATION
}

\author{
Kaan Gunduz ${ }^{1}$, Gozde Serindere ${ }^{2}$, Hakan Avsever ${ }^{3}$ and Kaan Orhan ${ }^{4}$ \\ ${ }^{1}$ Ondokuz Mayıs University, Faculty of Dentistry, Department of Dentomaxillofacial Radiology, Samsun, Turkey; \\ ${ }^{2}$ Hatay Mustafa Kemal University, Faculty of Dentistry, \\ Department of Dentomaxillofacial Radiology, Hatay, Turkey; \\ ${ }^{3}$ Health Sciences University, Gulhane Faculty of Dentistry, \\ Department of Dentomaxillofacial Radiology, Ankara, Turkey; \\ ${ }^{4}$ Ankara University, Faculty of Dentistry, Department of Dentomaxillofacial Radiology, Ankara, Turkey
}

\begin{abstract}
SUMMARY - The aim of the study was to evaluate accessory foramina (AF) located on the medial aspect and to present a unique finding of 'coronoid foramina' (CF) along with AF on the mandible. The cone beam computed tomography images of the mandible in 979 patients were retrospectively evaluated for the presence of $\mathrm{CF}$ and AF. AF was found in 39 (3.98\%) patients. AF located on the medial surface below and above mandibular foramen was found in $15.38 \%$ and $84.62 \%$ of patients, respectively. CF was confirmed in 20 (2.04\%) patients. Mandibular AF is important for surgical procedures in the posterior region of the mandible and for mandibular nerve anesthesia. This study including $\mathrm{CF}$ will be useful for further studies due to the lack of literature on the issue.
\end{abstract}

Key words: Mandible; Mandibular nerve; Cone-beam computed tomography

\section{Introduction}

The location and configuration of the mandibular canal are significant for surgical treatments in the mandible, such as impacted third molar extraction, dental implant practice, and sagittal split ramus osteotomy $^{1}$. The mandibular canal begins with the mandibular foramen (MF). If MF is single, it runs anteriorly arching along the trabecular bone to the region of medial incisor alveolus. Mandibular canal is wide near the mental foramen, and begins to narrow medially ${ }^{2,3}$. The inferior alveolar nerve is the main sensory branch of the mandibular nerve posterior trunk. Teeth and gingiva, and additionally mucosa, skin of lower lip and

Correspondence to: Asst. Prof. Gozde Serindere, Department of Dentomaxillofacial Radiology, Faculty of Dentistry, Hatay Mustafa KemalUniversity, 31060 Hatay, Turkey

E-mail: gozdeserindere@mku.edu.tr

Received September 25, 2018, accepted January 14, 2019 chin are supplied by this nerve. It anteriorly exists in the mandibular canal ${ }^{4}$.

The entity of the nerve is embryologically assumed to represent a presupposition to cause osteogenesis, followed by mandibular foramen and canal formation. During normal formation of the mandible, the accessory nerve is positioned on the inner side of the new formation of the mandible with Meckel's cartilage ${ }^{5}$.

Variations of the mandible such as the mandibular accessory foramina (AF) cause some implications in clinical practice and may lead to some complications if not previously determined ${ }^{6}$. AFs can involve nerve fibers or blood vessels. If they involve nerve fibers, local anesthesia may fail because of the nerve branches passing through the drug. Because it may contain accessory blood vessels, this can cause difficulty to control intraosseous hemorrhage ${ }^{7}$.

Mandibular AF is an opening apart from alveolar sockets, mandibular and mental foramina, and con- 
stant structure in the mandible ${ }^{8}$. It is commonly observed in the posterior mandible and symphysis region. It is more frequently found on the medial surface of the mandible than on the lateral surface ${ }^{9}$. Bilateral symmetry is frequent but variations are observed in size, number and shape ${ }^{10}$.

The term 'coronoid' derives from the Greek word for raven or crow. This is a bone projection that looks like a crow's beak. The term 'process' comes from Latin word which means 'to move forward', signifying a bone projection ${ }^{11}$.

Knowledge the presence of such foramina is clinically important because it can lead to diagnostic and therapeutic misinterpretations. The unawareness of these anatomic variations may cause adverse effects and failure in anesthesia during surgical procedures ${ }^{10}$.

Cone-beam computed tomography (CBCT) provides finely exhaustive scanning of the osseous structures with high contrast and burn out does not exist. Additionally, fine osseous structure may be evaluated even without lost data ${ }^{12}$. So, nowadays, CBCT is more effectively used to confirm the presence of AF which may not be evaluated with the conventional imaging modalities ${ }^{13}$.

Regarding the lack of literature, especially on coronoid foramina $(\mathrm{CF})$, our study was undertaken to evaluate the contents and incidence of mandibular AF and $\mathrm{CF}$ in a Turkish population and to lay emphasis on this unfamiliar anatomical structure.

\section{Material and Methods}

Images of 979 patients having undergone CBCT examination of the mandible for several reasons from the archives of the Health Sciences University, Gulhane Faculty of Dentistry, Department of Dentomaxillofacial Radiology were evaluated. Patient gender and age were recorded. There were 450 (45.97\%) females and $529(54.03 \%)$ males, age range 12-81, mean age 36.76 years. Fractures, pathologies such as cysts, tumors and images with artifacts were excluded; thus, 290 of 1269 images were excluded because of insufficient quality, low field of view size, fracture or pathologies in the posterior region of mandible.

Between April 2013 and December 2017, CBCT scans were obtained using a 3D Accuitomo $170 \mathrm{CBCT}$ device (Morita Manufacturing Corp., Kyoto, Japan) with $90 \mathrm{kV}$ and $5 \mathrm{~mA}$. Exposure time of 17.5 seconds was used for all images. The CBCT machine had 140x100 mm field of view, and the voxel size was 0.08 $\mathrm{mm}$. All images were analyzed with software (i-Dixel one volume viewer 2.0) for reconstruction of sagittal, axial, coronal and three-dimensional images and each image was retrospectively evaluated by a single oral and maxillofacial radiologist. In doubtful cases, a dentomaxillofacial radiologist $(\mathrm{KG})$ with at least 10 -year experience was consulted. The patient was placed in such a position that the occlusal plan would be parallel to the floor by using ear rods and a chinrest during scanning. The incidence and location of AF and CF were noted. The distance between $\mathrm{MF}$ and $\mathrm{AF}$ was measured with CBCT unit software (Figs. 1 and 2). All evaluations and measurements were performed on a 15.6-inch monitor with resolution of $1366 \times 768$.

\section{Statistical analysis}

The data obtained in this study were analyzed using IBM SPSS Statistics Version 22 package program. Descriptive statistics such as number, mean, standard deviation for the variables are shown in tables. Shapiro Wilk's test was used because of the unit numbers while investigating normal distribution of the variables. On interpretation of the results, the level of significance was set at 0.05 ; in case of $\mathrm{p}<0.05$, the variables did not follow normal distribution, whereas in case of $p>0.05$ the variables did follow normal distribution. Mann Whitney $U$ test was used because the variables did not differ from normal distribution. The $\chi^{2}$ analysis was applied when relations between the groups of nominal variables were examined. Fisher exact test was used when the expected values in the $2 \times 2$ tables did not have sufficient volume and Pearson $\chi^{2}$ analysis was applied with $\mathrm{RxC}$ tables using Monte Carlo simulation (20\% of the expected value is smaller than 5 , so $\chi^{2}$ analysis was done with the help of Monte Carlo simulation). On interpretation of the results, the level of significance was set at 0.05 , i.e. $\mathrm{p}<0.05$ values were considered significant.

\section{Results}

Accessory foramina were found in $3.98 \%$ and $\mathrm{CF}$ in $20(2.04 \%)$ patients. CF was present unilaterally in 14 (70\%) and bilaterally in $6(30 \%)$ patients. The mean age of study patients was 36.76 , age range $12-81$ years. The mean distance between $\mathrm{MF}$ and $\mathrm{AF}$ was $14.59 \mathrm{~mm}$. 
Table 1. Frequency distribution of demographic and clinical data

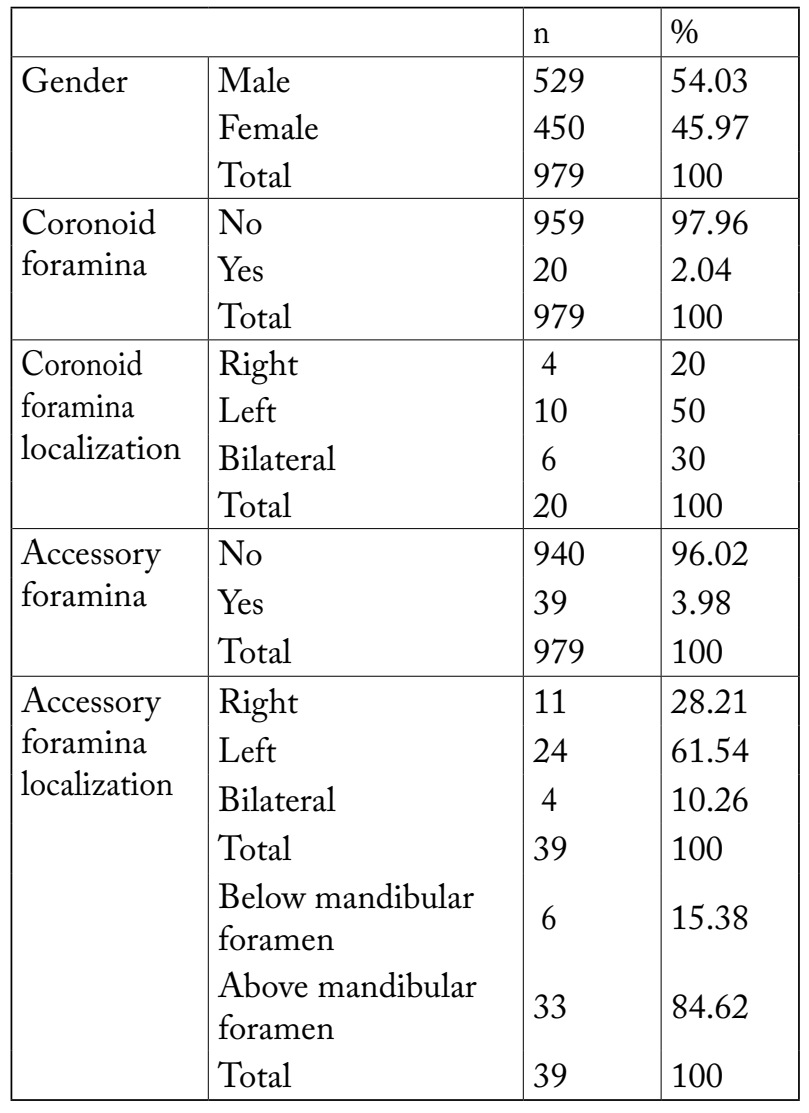

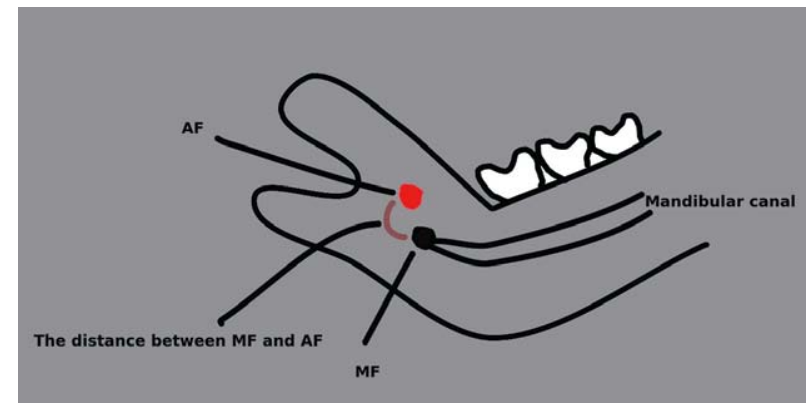

Fig. 1. A drawing of the mandible illustrating mandibular accessory foramina and mandibular foramen (based on the study by Narayana and Prashanthi ${ }^{21}$ ).

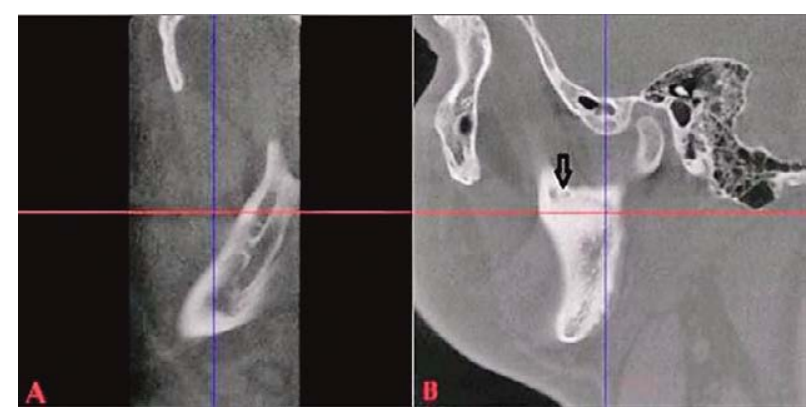

Fig. 2. Cone beam computed tomography images: (A) bifid mandibular canal; (B) coronoid foramina.

Table 2. Frequency distribution of coronoid foramina according to other variables

\begin{tabular}{|c|c|c|c|c|c|c|c|}
\hline & \multicolumn{6}{|c|}{ Coronoid foramina } \\
\hline & & \multicolumn{2}{|c|}{ Not found } & \multicolumn{2}{|c|}{ Found } & \multicolumn{2}{|c|}{ Total } \\
\hline & & $\mathrm{n}$ & $\%$ & $\mathrm{n}$ & $\%$ & $\mathrm{n}$ & $\%$ \\
\hline \multirow[t]{3}{*}{ Gender } & Male & 520 & 54.22 & 9 & 45 & 529 & 54.03 \\
\hline & Female & 439 & 45.78 & 11 & 55 & 450 & 45.97 \\
\hline & Total & 959 & 100 & 20 & 100 & 979 & 100 \\
\hline \multirow{10}{*}{$\begin{array}{l}\text { Accessory foramina } \\
\text { localization }\end{array}$} & No & 920 & 95.93 & 20 & 100 & 940 & 96.02 \\
\hline & Yes & 39 & 4.07 & 0 & 0 & 39 & 3.98 \\
\hline & Total & 959 & 100 & 20 & 100 & 979 & 100 \\
\hline & Right & 11 & 28.21 & 0 & 0 & 11 & 28.21 \\
\hline & Left & 24 & 61.54 & 0 & 0 & 24 & 61.54 \\
\hline & Bilateral & 4 & 10.26 & 0 & 0 & 4 & 10.26 \\
\hline & Total & 39 & 100 & 0 & 0 & 39 & 100 \\
\hline & Below mandibular foramen & 6 & 15.38 & 0 & 0 & 6 & 15.38 \\
\hline & Above mandibular foramen & 33 & 84.62 & 0 & 0 & 33 & 84.62 \\
\hline & Total & 39 & 100 & 0 & 0 & 39 & 100 \\
\hline
\end{tabular}


Table 3. Frequency distribution of accessory foramina localization according to other variables

\begin{tabular}{|c|c|c|c|c|c|c|c|}
\hline & \multicolumn{6}{|c|}{ Accessory foramina } \\
\hline & & \multicolumn{2}{|c|}{ Absent } & \multicolumn{2}{|c|}{ Present } & \multicolumn{2}{|c|}{ Total } \\
\hline & & $\mathrm{n}$ & $\%$ & $\mathrm{n}$ & $\%$ & $\mathrm{n}$ & $\%$ \\
\hline \multirow[t]{3}{*}{ Gender } & Male & 503 & 53.51 & 26 & 66.67 & 529 & 54.03 \\
\hline & Female & 437 & 46.49 & 13 & 33.33 & 450 & 45.97 \\
\hline & Total & 940 & 100 & 39 & 100 & 979 & 100 \\
\hline \multirow[t]{3}{*}{ Coronoid foramina } & No & 920 & 97.87 & 39 & 100 & 959 & 97.96 \\
\hline & Yes & 20 & 2.13 & 0 & 0 & 20 & 2.04 \\
\hline & Total & 940 & 100 & 39 & 100 & 979 & 100 \\
\hline \multirow{4}{*}{$\begin{array}{l}\text { Coronoid foramina } \\
\text { localization }\end{array}$} & Right & 4 & 20 & 0 & 0 & 4 & 20 \\
\hline & Left & 10 & 50 & 0 & 0 & 10 & 50 \\
\hline & Bilateral & 6 & 30 & 0 & 0 & 6 & 30 \\
\hline & Total & 20 & 100 & 0 & 0 & 20 & 100 \\
\hline \multirow{7}{*}{$\begin{array}{l}\text { Accessory foramina } \\
\text { localization }\end{array}$} & Right & 0 & 0 & 11 & 28.21 & 11 & 28.21 \\
\hline & Left & 0 & 0 & 24 & 61.54 & 24 & 61.54 \\
\hline & Bilateral & 0 & 0 & 4 & 10.26 & 4 & 10.26 \\
\hline & Total & 0 & 0 & 39 & 100 & 39 & 100 \\
\hline & Below mandibular foramen & 0 & 0 & 6 & 15.38 & 6 & 15.38 \\
\hline & Above mandibular foramen & 0 & 0 & 33 & 84.62 & 33 & 84.62 \\
\hline & Total & 0 & 0 & 39 & 100 & 39 & 100 \\
\hline
\end{tabular}

Table 4. Results of $\chi^{2}$-test on the relationship between accessory foramina localization and other variables

\begin{tabular}{|l|l|l|l|l|l|}
\hline \multicolumn{2}{|l|}{} & $\mathrm{n}$ & $\%$ & $\chi^{2}$-test & $\mathrm{p}$ \\
\hline Gender & Male & 26 & 66.67 & 0.331 & 0.565 \\
& Female & 13 & 33.33 & & \\
& Total & 39 & 100 & & \\
\hline Accessory foramina & Right & 11 & 28.21 & Fisher exact & 0.706 \\
& Left & 24 & 61.54 & test & \\
& Bilateral & 4 & 10.26 & & \\
& Total & 39 & 100 & & \\
\cline { 2 - 5 } & Below mandibular foramen & 6 & 15.38 & Fisher exact & 0.37 \\
& Above mandibular foramen & 33 & 84.62 & test & \\
& Total & 39 & 100 & & \\
\hline
\end{tabular}

Analysis for $\mathrm{CF}$ revealed its absence in $97.96 \%$ and presence in $2.04 \%$ of patients. In those with CF, $50 \%$ were on the left, $30 \%$ bilateral and $20 \%$ on the right. AF was absent in $96.02 \%$ and present in $3.98 \%$ of patients. According to AF localization, $61.54 \%$ were on the left, $28.21 \%$ on the right and $10.26 \%$ bilateral. In $84.62 \%$ and $15.38 \%$ of patients with AF, it was positioned above and below MF, respectively (Table 1).
There was no statistically significant difference in the presence of $\mathrm{CF}$ according to age ( $\mathrm{p}>0.05)$; however, patients with $\mathrm{CR}$ were older, but the difference was not statistically significant. Of the patients with no CF, $54.22 \%$ were male and $45.78 \%$ female. Of those with $\mathrm{CF}, 45 \%$ were male and $55 \%$ female. Of the patients without $\mathrm{CF}, 95.93 \%$ had no AF, whereas 4.07\% had AF. AF was absent in all patients with CF (100\%). 
Table 5. Results of $\chi^{2}$-test on the relationship between accessory foramina localization and other variables

\begin{tabular}{|c|c|c|c|c|c|c|c|c|c|}
\hline & \multicolumn{6}{|c|}{ Accessory foramina (below/above mandibular foramen) } & \multirow[b]{3}{*}{$\chi^{2}$-test } & \multirow[b]{3}{*}{$p$} \\
\hline & & \multicolumn{2}{|c|}{ Below } & \multicolumn{2}{|c|}{ Above } & \multicolumn{2}{|c|}{ Total } & & \\
\hline & & $\mathrm{n}$ & $\%$ & $\mathrm{n}$ & $\%$ & $\mathrm{n}$ & $\%$ & & \\
\hline Gender & \begin{tabular}{|l} 
Male \\
Female \\
Total \\
\end{tabular} & $\begin{array}{l}3 \\
3 \\
6\end{array}$ & \begin{tabular}{|l|}
50 \\
50 \\
100 \\
\end{tabular} & $\begin{array}{l}23 \\
10 \\
33 \\
\end{array}$ & \begin{tabular}{|l|}
69.7 \\
30.3 \\
100 \\
\end{tabular} & $\begin{array}{l}26 \\
13 \\
39 \\
\end{array}$ & $\begin{array}{l}66.67 \\
33.33 \\
100 \\
\end{array}$ & $\begin{array}{l}\text { Fisher } \\
\text { exact test }\end{array}$ & 0.38 \\
\hline $\begin{array}{l}\text { Accessory foramina } \\
\text { localization }\end{array}$ & \begin{tabular}{|l|} 
Right \\
Left \\
Bilateral \\
Total \\
\end{tabular} & $\begin{array}{l}3 \\
2 \\
1 \\
6\end{array}$ & \begin{tabular}{|l|}
50 \\
33.33 \\
16.67 \\
100 \\
\end{tabular} & \begin{tabular}{|l|}
8 \\
22 \\
3 \\
33 \\
\end{tabular} & $\begin{array}{l}24.24 \\
66.67 \\
9.09 \\
100 \\
\end{array}$ & $\begin{array}{l}11 \\
24 \\
4 \\
39 \\
\end{array}$ & \begin{tabular}{|l|}
28.21 \\
61.54 \\
10.26 \\
100
\end{tabular} & * & 0.293 \\
\hline
\end{tabular}

*Monte Carlo method used for analysis when the number of subjects per eye in $\chi^{2}$ analysis was insufficient.

Table 6. Results of $\chi^{2}$-test on the relationship between age groups and coronoid/accessory foramina

\begin{tabular}{|c|c|c|c|c|c|c|c|c|c|c|c|c|c|}
\hline & \multicolumn{10}{|c|}{ Age (yrs) } & \multirow[b]{3}{*}{$\chi^{2}$-test } & \\
\hline & & \multicolumn{2}{|l|}{$\leq 20$} & \multicolumn{2}{|c|}{ 20-39 } & \multicolumn{2}{|c|}{$40-59$} & \multicolumn{2}{|l|}{$60 \geq$} & \multicolumn{2}{|c|}{ Total } & & \\
\hline & & $\mathrm{n}$ & $\%$ & $\mathrm{n}$ & $\%$ & $\mathrm{n}$ & $\%$ & $\mathrm{n}$ & $\%$ & $\mathrm{n}$ & $\%$ & & $\mathrm{p}$ \\
\hline \multirow{3}{*}{$\begin{array}{l}\text { Coronoid } \\
\text { foramina }\end{array}$} & Not found & 260 & 98.86 & 279 & 97.55 & 302 & 97.42 & 118 & 98.33 & 959 & 97.96 & 1.837 & 0.607 \\
\hline & Found & 3 & 1.14 & 7 & 2.45 & 8 & 2.58 & 2 & 1.67 & 20 & 2.04 & & \\
\hline & Total & 263 & 100 & 286 & 100 & 310 & 100 & 120 & 100 & 979 & 100 & & \\
\hline \multirow{3}{*}{$\begin{array}{l}\text { Accessory } \\
\text { foramina }\end{array}$} & Not found & 252 & 95.82 & 271 & 94.76 & 299 & 96.45 & 118 & 98.33 & 940 & 96.02 & 3.054 & 0.383 \\
\hline & Found & 11 & 4.18 & 15 & 5.24 & 11 & 3.55 & 2 & 1.67 & 39 & 3.98 & & \\
\hline & Total & 263 & 100 & 286 & 100 & 310 & 100 & 120 & 100 & 979 & 100 & & \\
\hline
\end{tabular}

Left AF was found in 61.54\%, right AF in $28.21 \%$ and bilateral AF in $10.26 \%$ of patients without CF. When $\mathrm{MF}$ was evaluated, $84.62 \%$ of patients without $\mathrm{CF}$ were found to have $\mathrm{AF}$ above $\mathrm{MF}$ and $15.38 \%$ below MF. Sex distribution revealed that $53.51 \%$ of patients without AF were male and $46.49 \%$ female. Of the patients with AF, $66.67 \%$ were male and $33.33 \%$ female. Among patients without AF, CF was absent in 97.87\% and present in $2.13 \%$. CF was absent in $100 \%$ of patients with $\mathrm{AF}$. When $\mathrm{CF}$ was evaluated, left $\mathrm{CF}$ was present in $50 \%$, bilateral $\mathrm{CF}$ in $30 \%$ and right $\mathrm{CF}$ in $20 \%$ of patients without AF (Tables 2 and 3). There was no statistically significant relationship between localization and other variables ( $p>0.05)$. Results of the $\chi^{2}$-test on the relationship between localization and other variables are shown in Table 4.

There was no statistically significant relationship between AF location and other variables ( $p>0.05)$. Although not statistically significant, $50 \%$ of patients with AF positioned below MF and $69.7 \%$ of patients with $\mathrm{AF}$ positioned above MF were male; $50 \%$ of pa- tients with $\mathrm{AF}$ positioned below $\mathrm{MF}$ and $30.3 \%$ of patients with AF positioned above MF were females. Detailed information is shown in Table 5.

There was no statistically significant relationship between age groups and other variables $(p>0.05)$. Results of the $\chi^{2}$-test on the relationship between age groups and $\mathrm{CF}$ are shown in Table 6. CF was absent in $98.3 \%$ of male and $97.56 \%$ of female patients. CF was present in $1.7 \%$ of male and $2.44 \%$ of female patients. Sex distribution showed $95.09 \%$ of males and $97.11 \%$ of females to have no AF, whereas $4.91 \%$ of males and $2.89 \%$ of females had AF. According to localization, CF was absent in $100 \%$ of the right, left and bilateral AF groups. AF was present in $100 \%$ of the right, left and bilateral CF groups. There was no CF in $100 \%$ of patients with $\mathrm{AF}$ below and above MF.

\section{Discussion}

Knowing variations in the mandibular canal is very important for dental implant and several surgical op- 
erations ${ }^{1}$. Embryologic number variations of the mandibular canal may be clarified because in the early development, the inferior alveolar nerve innervates the anterior teeth, premolar and molar region independently ${ }^{14}$. The first description of AF was associated with irrigation and veined drainage of deciduous teeth and of the alveolar processes in formation. This canal has progressive obliteration from birth to the first year of life. Persistence of a foramen to the adult period is considered anatomic variation ${ }^{15}$.

The phylogenetic hypothesis for $\mathrm{CF}$ of the mandible implies that CF has not yet been observed bilaterally in humans or in other proboscideans except for elephantines ${ }^{10}$. Ferretti and Debruyne ${ }^{16}$ in their article from 2011 commented a sample of 'Elephas Maximus' as having a $\mathrm{CF}$ which "merged with the alveolus of the distal most erupting molar" to form a coronoid canal. This coronoid canal was first described by Tassy and Shoshani as a synapomorphy of paenungulates in $1988^{17}$. Further studies of human morphology are necessary to understand better this anatomic variation.

In the literature, $\mathrm{AF}$ incidence rates are different due to the investigation of different numbers of mandibles, methods, sample size and criteria ${ }^{8}$. Przysatńska and $\mathrm{Bruska}^{8}$ report that at least one $\mathrm{AF}$ was observed in $96 \%$ of adult mandibles investigated. Gupta et al. ${ }^{7}$ report on AF found in $48 \%$ of cases. Shalini et al. ${ }^{18}$ found double AF unilaterally in 17 (8.33\%) and bilaterally in $3(1.5 \%)$ mandibles. Suazo et al. ${ }^{19}$ report on $42.6 \%$ incidence of mandibular AF, whereas Choi and $\mathrm{Han}^{20}$ recorded a lower AF incidence of $1.35 \%$. Narayana and Prashanthi ${ }^{21}$ report on only one large mandibular AF (0.3\%) found in 335 dry mandibles. In our study, AF was observed in $3.98 \%$ of patients.

In 2005, Kilarkaje et al. ${ }^{22}$ reported that the location of MF showed bilateral symmetry regardless of age. However, Freire et al. ${ }^{15}$ recorded AF on the right and left sides in $17.12 \%$ and $16.22 \%$ of cases, respectively. In our study, $\mathrm{AF}$ was more frequently observed on the left side but there was no statistically significant relationship between localization and other variables.

Choi and $\mathrm{Han}^{20}$ report that all double MF were located above the MF on the medial aspect of the mandible. In the study by Freire et al. ${ }^{15}, 27.93 \%$ and $43.24 \%$ of the mandibles presented at least one AF located on the medial surface in position below and above the MF, respectively. Unilaterally, mandibular AF were observed below and above the MF in 22.07\% and $25.22 \%$ of the mandibles, respectively, and $5.85 \%$ and $18.02 \%$ bilaterally, respectively ${ }^{15}$. In our study, AF was found in $15.38 \%$ and $84.92 \%$ of patients on the medial surface in position below and above the MF, respectively.

In comparison to multi slice computed tomography (MSCT), CBCT has some major advantages. The first is that the radiation dose is relatively $l_{0} \mathrm{w}^{23,24}$. The second reason is wide and effective use of CBCT in dental clinics, while MSCT usage is generally limited to hospitals. As a third reason, resolution in CBCT images was higher than in MSCT images ${ }^{25}$. So, we preferred using $\mathrm{CBCT}$ to evaluate $\mathrm{AF}$ and $\mathrm{CF}$ of the mandible in this study.

Dental implants have been used for more than 20 years in Turkey. The presumed rate of dental implant operations is about 350,000 per year. This number corresponds approximately to $4 \%$ of the total population. Although being on an increase, it is observed that the numbers of population-implant consumption in Turkey are far behind those recorded in developed countries worldwide ${ }^{26}$. In a pilot study from northern east Turkey, 1316 of 5000 patients had indications for tooth extraction ${ }^{27}$. Dentists should be guiding their patients and inform them about oral health protection such as tooth brushing ${ }^{28}$. Thus, it is possible to minimize the indications for tooth extraction in the community. However, in our country, the high rate of tooth extraction makes it even more important to know the variations of a relevant anatomic landmark such as the mandibular canal. Also, it has been reported that mandibular AF provides an easy way for tumor spread following radiotherapy ${ }^{29,30}$.If $\mathrm{AF}$ is present, the clinicians must be careful when planning radiotherapy ${ }^{20}$.

Better information about variations of anatomic landmarks will help the surgeon prevent complications. For this reason, extensive and detailed preoperative radiologic assessment should be performed using proper imaging techniques. Besides, appropriate information on the anatomy will help dentists achieve success in treatment planning and prevent wrong interpretation and treatment ${ }^{31}$.

In conclusion, bifid mandibular canal was previously found in $3.05 \%$ of patients in a Turkish population by use of $\mathrm{CBCT}^{32}$. We wanted to perform a more detailed investigation of the mandibular canal variations. To the best of our knowledge, there is only one case report on $\mathrm{CF}$ in the literature ${ }^{10}$. So, this will be the 
first study of $\mathrm{CF}$ as an unfamiliar anatomic variation. Additional studies are needed to better understand and discuss the CF issue and we hope this study will be useful for future investigations.

\section{References}

1. Naitoh M, Hiraiwa $Y$, Aimiya $H$, Gotoh $M$, Ariji $Y$, et al. Bifid mandibular canal in Japanese. Implant Dent. 2007;16:24-32. 10.1097/ID.0b013e3180312323

2. Juodzbalys G, Wang HL, Sabalys G. Anatomy of mandibular vital structures. Part II: Mandibular incisive canal, mental foramen and associated neurovascular bundles in relation with dental implantology. J Oral Maxillofac Res. 2010;1:e3. 10.5037/ jomr.2010.1103

3. Juodzbalys G, Wang HL, Sabalys G. Anatomy of mandibular vital structures. Part I: Mandibular canal and inferior alveolar neurovascular bundle in relation with dental implantology. J Oral Maxillofac Res. 2010;1(1):e2. 10.5037/jomr.2010.1102

4. Rake RL, Vogl AW, Mitchell AW. Gray's Anatomy for Students. $2^{\text {nd }}$ edn. Philadelphia: Elsevier; 2012. p. 935.

5. Manikandhan R, Mathew PC, Naveenkumar J, Anatanarayanan P. A rare variation in the course of the inferior alveolar nerve. Int J Oral Maxillofac Surg. 2010;39:185-7. 10.1016/j. ijom.2009.12.007

6. Claeys V,Wackens G. Bifid mandibular canal: literature review and case report. Dentomaxillofac Radiol. 2005;34:55-8. 0.1259 $/ \mathrm{dmfr} / 23146121$

7. Gupta S, Soni A, Singh P. Morphological study of accessory foramina in mandible and its clinical implication. Indian J Oral Sci. 2013;4:12-6. 10.4103/0976-6944.118512

8. Przystanska A, Bruska M. Anatomical classification of accessory foramina in human mandibles of adults, infants and fetuses. Anat Sci Int. 2012;87:141-9. 10.1007/s12565-0120136-z

9. Sutton RN. The practical significance of mandibular accessory foramina. Aust Dent J. 1974;19:167-73.

10. Subhan NFC. Bilateral 'coronoid foramina' with accessory foramina on the 'lateral aspect of ramus' of mandible: an unseen variance discovery in humans. Surg Radiol Anat. 2018;40: 641-6. 10.1007/s00276-018-1984-6

11. Duckworth WLH, Lyons MC, Towers B, editors. Galen on Anatomical Procedures: the Later Books. Cambridge: Cambridge University Press; 1962.

12. Miller RJ, Edwards WC, Boudet C, Cohen JH. Maxillofacial anatomy: the mandibular symphysis. J Oral Implantol. 2011; 37:745-53.10.1563/aaid-joi-d-10-00136

13. Naitoh M, Nakahara K, Suenaga Y, Gotoh K, Kondo S, et al. Variations of the bony canal in the mandibular ramus using cone-beam computed tomography. Oral Radiol. 2010;26(1): 36-40. 10.1007/s11282-009-0030-0

14. Chávez-Lomeli ME, Mansilla Lory J, Pompa JA, Kjaer I. The human mandibular canal arises from three separate canals in- nervating different tooth groups. J Dent Res. 1996;75:1540-4. https://doi.org/10.1177/00220345960750080401

15. Freire AR, Rossi AC, Prado FB, Caria PHF, Botacin PR. Incidence of the mandibular accessory foramina in Brazilian population. J Morphol Sci. 2012;29(3):171-3.

16. Ferretti MP, Debruyne R. Anatomy and phylogenetic value of the mandibular and coronoid canals and their associated foramina in proboscideans (Mammalia). Zool J Linn Soc. 2011; 161:391-413. 10.1111/j.1096-3642.2010.00637.x

17. Tassy P, Shoshani J. The tethytheria: elephants and their relatives. In: Benton MJ, editor. The Phylogeny and Classification of the Tetrapods. Vol 2: Mammals. Systematic Association. Special Vol. 35B. Oxford: Clarendon Press; 1988. p. 283-315.

18. Shalini R, Ravi Varman C, Manoranjitham R, Veeramuthu M. Morphometric study on mandibular foramen and incidence of accessory mandibular foramen in mandibles of south Indian population and its clinical implications in inferior alveolar nerve block. Anat Cell Biol. 2016;49:241-8. 10.5115/acb. 2016.49.4.241

19. Suazo GIC, Zavando MDA, Smith RL. Is the conduct of Serres an anatomical variation in adults? Int J Morphol. 2009;27(1):43-7. http://dx.doi.org/10.4067/S0717-95022009 000100008.

20. Choi YY, Han SS. Double mandibular foramen leading to the accessory canal on the mandibular ramus. Surg Radiol Anat. 2014;36:851-5. 10.1007/s00276-014-1310-x

21. Narayana K, Prashanthi N. Incidence of large accessory mandibular foramen in human mandibles. Eur J Anat. 2003; 7(3):139-41.

22. Kilarkaje N, Nayak SR, Narayan P, Prabhu LV. The location of the mandibular foramen maintains absolute bilateral symmetry in mandibles of different age-groups. Hong Kong Dent J. 2005;2:35-7.

23. Ludlow JB, Ivanovic M. Comparative dosimetry of dental CBCT devices and 64-slice CT for oral and maxillofacial radiology. Oral Surg Oral Med Oral Pathol Oral Radiol Endod. 2008;106:106-14. 10.1016/j.tripleo.2008.03.018

24. Okano T, Hirata Y, Sugihara Y, Sakaino R, Tsuchida R, Iwai K, et al. Absorbed and effective doses from cone-beam volumetric imaging for implant planning. Dentomaxillofac Radiol. 2009; 38:79-85. 10.1259/dmfr/14769929.

25. Naitoh M, Katsumata A, Mitsuya S, Kamemoto H, Ariji E. Measurement of mandibles with microfocus $\mathrm{x}$-ray computerized tomography and compact computerized tomography for dental use. Int J Oral Maxillofac Implants. 2004;19:239-46. PMID:15101596

26. Implantder. Implantder Dental Implant Sektor Raporu, 2015.

27. Kırtıloğlu T, Açıkgöz A, Sakallıŏlu U, Açıkgöz G. Reasons for extraction of permanent teeth in the northern east of Turkey: a pilot study. Ondokuz Mayıs Üniversitesi Dişhekimliği Fakültesi Dergisi. 2002;3(2):80-3.

28. Lujo M, Meštrović M, Malčić AI, Karlović Z, Matijević J, Jukić $\mathrm{S}$. Knowledge, attitudes and habits regarding oral health in 
first-and final-year dental students. Acta Clin Croat. 2016; 55:636-43. 10.20471/acc.2016.55.04.15

29. Das S, Suri R. An anatomico-radiological study of an accessory mandibular foramen on the medial mandibular surface. Folia Morphol. 2004;63:511-3. PMID:15712153

30. Fanibunda K, Matthews JN. The relationship between accessory foramina and tumour spread on the medial mandibular surface. J Anat. 2000;196(Pt 1):23-9. 10.1046/j.1469-7580. 2000.19610023.x
31. Ozgedik S, Karacayli U, Ozarslanturk S, Avsever H, Orhan K. Trifid mandibular canal and lingual accessory mental foramen: a case of two rare anatomical variations. Dentistry Adv Res. 2017: DTAR-136. 10.29011/2574-7347.100036

32. Serindere G, Gündüz K, Bulut E. Investigation of bifid mandibular canal frequency with cone beam computed tomography in a Turkish population. Anatomy. 2017;11(1):30-6. 10.2399/ ana.16.060

Sažetak

\title{
DETALJNA PROCJENA 'KORONOIDNIH FORAMENA' I POMOĆNIH FORAMENA MANDIBULE POMOĆU CBCT: JEDINSTVENA ANATOMSKA VARIJACIJA
}

\author{
K. Gunduz, G. Serindere, H. Avsever i K. Orhan
}

Cilj istraživanja bio je procijeniti pomoćne foramene (PF) smještene na medijalnom dijelu i prikazati jedinstven nalaz 'koronoidnih foramena' (KF) uz PF na mandibuli. Snimke mandibule u 979 pacijenata dobivene tehnikom CBCT (cone beam computed tomography) retrospektivno su procijenjene na prisutnost PF i KF. PF je nađen u 39 (3,98\%) pacijenata. PF smješten na medijalnoj površini ispod i iznad mandibularnog foramena uvrđen je u $15,38 \%$ odnosno $84,62 \%$ pacijenata. KF je potvrđen u 20 (2,04\%) pacijenata. Mandibularni PF je važan za kirurške zahvate u stražnjem dijelu mandibule, kao i za anesteziju mandibularnog živca. Zbog nedostatka literature o ovom pitanju, ovo istraživanje koje je obuhvatilo KF bit će korisno za buduće istraživanje u ovom području.

Ključne riječi: Mandibula; Mandibularni živac; Cone-beam kompjutorizirana tomografija 